\title{
The Ostracod Genus Actinocythereis From The Middle Miocene of Northern Iraq
}

\author{
SALEH K. KHALAF \\ Department of Geology, Mosul University, Mosul, Iraq.
}

\begin{abstract}
Four species and one subspecies of the trachyleberid Ostracod genus Actinocythereis from the lower Fars Formation (Middle Miocene) of Northern Iraq are described for the first time. All of them are new and they show strong affinities with the species described from the Tertiary of
\end{abstract} Western India.

\section{INTRODUCTION}

The area studied lies in Northern Iraq in the central unit of the foothill Zone, in which nine sections of the Lower Fars Formation (Middle Miocene) were chosen across the basin extending from NW to the SE. Five of these sections are located in the Sinjar area, the others in the Kirkuk area, in which the surface samples were collected during field work in Western Iraq in 1980, and the subsurface samples were obtained from Northern oil fields material released by the Ministry of oil (Fig. 1). The Ostracod genus Actinocythereis occurs abundantly in the Middle Miocene of N. Iraq, where it is represented by four species and one subspecies, namely; A. iraqensis Khalaf 1982, A.costata sp. nov., A.cornuocula cornucula sp.nov. A. dextraspina sp.nov. A. cornuocula spinosa, ssp.nov. A literature survey shows that this genus has not been recorded before from Iray and the adjacent areas. However, other related species are described from the Eocene, Oligocene and Miocene of western India and Burma. A comparative study of this genus between Iraq, Turkey and the western Indopacific is needed and should prove most fruitful. It is proposed to undertake this in the near future.

This paper is taken from the Ph.D thesis completed at the University of Hull in 1984.

All the figured specimens are deposited in the Hull University, Geology Department, Tertiary collection.

\section{SYSTEMATIC DESCRIPTIONS}

Family Trachyle berididue Sylvester-Bradley 1948

Subfamily Trachyleberidinae Sylvester-Bradley 1948

Tribe Trachyleheridini Sylvester-Bradley 1948

Genus Actinocythereis Puri 1953

Type species. Cythere exanthemata Uirich and Bassler 1904

Artinocythereis iraqensis Khataf 1982

(Pl.1 figs. 1-6)

1982 Actinocythereis iraqensis Khalaf:9 (9)51-54.

Holotype, male carapace HU.275 T.6.

Paratypes. female carapace. HU.275 T.7.1; female LV, int. lat, HU.275 T.8; male carapace, HU.275 T.7.2; male RV, int. lat, HU.275 T.7.3.

Material. 350 specimens.

Horizon. M. Miocene, L.Fars Formation, bed no. 50, sample no. SHI. 28.

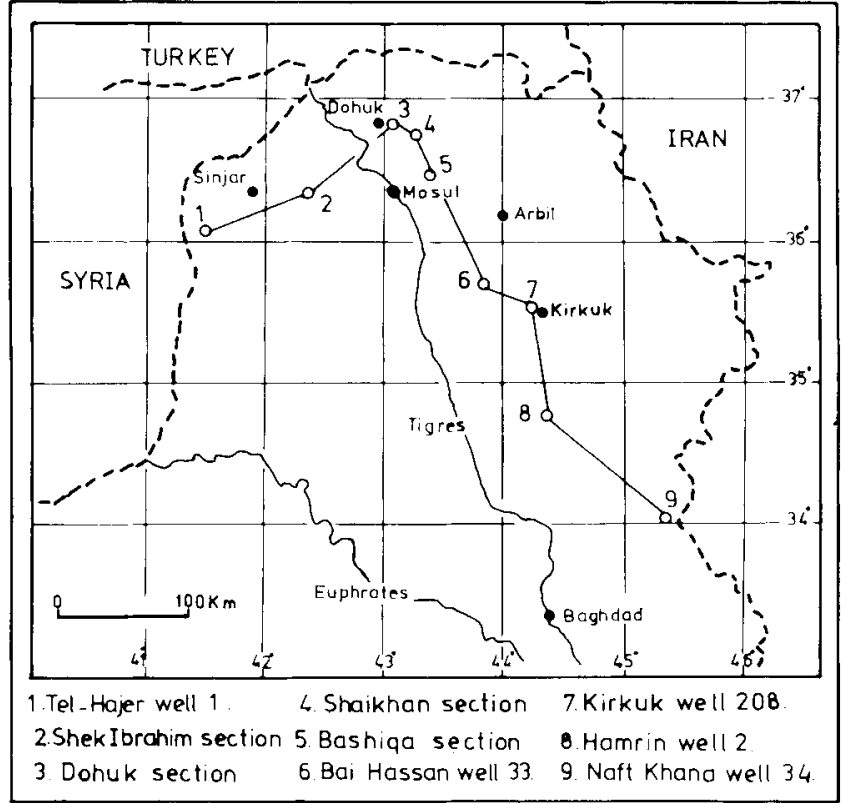

Fig. 1. Location map for the sections studied.

Locality. Sheikh Ibrahim anticline, S.limb, Sheikh Ibrahim Section (Fig. 1) NW Iraq, 45 km west of Mosul City.

Description. Thick-shelled, elongate carapace, subrectangular in lateral view with greatest height at the eye tubercle; greatest length nearly at mid-height. Anterior end rounded, with distinct thick anterior marginal rim, decorated with double row of small nodes, posterior and subtriangular slightly pointed centrally, decorated with row of small nodes. Dorsal and ventral margins straight and nearly subparallel, anterior and posterior cardinal angles more distinct in the left valve. Surface coarsely ornamented with different sized tubercles. The median row runs obliquely anteroventrally to posterodorsally and consists of five tubercles of which the posterodorsal tubercles are smaller than the two anterior ones; the ventral row which lies below the median row is formed of four to five tubercles, the middle two of which are double; there is a curved dorsal row of eight tubercles, which anteriorly dips below the prominent eye tubercle, some of the posterior ones are doubled. The rows of tubercles form the elevated parts of the shell with shallow furrows in between. There is a more distinct furrow behind the anterior marginal rim, which is bounded dorsally by a thick short ridge, which is connected with a small node between the eye tubercle and sub-central tubercle. In dorsal view, posterior end narrower 
than the broadly rounded anterior end, tubercles are prominent and break up the outline of the carapace and the maximum width and thickness is at the middle.

Internally deep valves; marginal zone moderately broad, marginal pore canals numerous, simple some clustered. Line of concrescence and inner margin coincide and runs subperipherally and is not strongly developed, strong anterior flange in both valve, muscle scars cannot be seen due to thick shell. Normal pore canals not numerous and of open type. Hinge in the left valve consists of an anterior deep rounded socket separated from the eye sinus by a thick curved ridge, a strong postjacent outstanding antero-median tooth, separated from deep quadriloculate posterior socket, by a thick crenulate elongate bar which terminates with a slight node above the posterior socket. In the right valve, a strong outstanding anterior tooth is followed by a deep postjacent socket, bounded by strong ridge emerging from the anterior tooth, a shallow crenulate posteromedian groove and a strong subconical posterior tooth. Sexual dimorphism marked, the presumed males more elongate and narrower than the presumed females; dimorphism is most distinct in dorsal view.

Dimensions of figured specimens (in $\mu \mathrm{m}$ ) Holotype, male carapace, HU.275 T.6 length 1092, height 570. Paratype, female carapace, HU.275 T.7.I length 916, height 530. Paratype, female LV, HU.275 T.8 length 956, height 550. Paratype, female carapace, HU.275 T. 7.2 length 940. height 55.5. Paratype, male RV. HU.275 T. 7.3 length 1000 , height 510

Remarks The present species shows affinities with Actinocythereis tumefacentis (Lyubimova and Guha, 1960) but the ventral margin of the latter species is strongly concave medially, and the posterior end is more rounded than that of $A$. iraqensis.

This species differs from Trachyleberis (Actinocythereis) birmanica pyawbwe Graham, 1975 which is narrow posteriorly.
Distribution. A. iraqensis was found in the Bashiqa, Sheikhan, Dohuk, Sheikh Ibrahim, Naft Khana, Tel-Hajer, Kirkuk and Hamrin sections of Northern Iraq. (fig. I).

Actinocythereis costata sp. nov.

(Pl. 1, figs. 7-12)

Derivation of name. With reference to the well developed ventral ridge in the lateral surface.

Diagnosis. A species of Actinoc ythere is, in which the dorsal margin is broken up by small tubercles with shallow furrows in between. Marginal flange starts from the anterior cardinal angle, runs parallel to the anterior margin and ventral margin to terminate posteriorly; a distinctive short ridge bounds the row of ventral tubercles, ventral margin straight in male, sinuate in the female.

Holotype. A male carapace HU.277 T.35.

Paratypes. Four specimens HU.277 T.36.1-4.

Type locality and horizon. Kikuk Well 208, northern Iray, depth 65.5-660m.

M.Micocene, L.Fars Formation.

Description. Medium-sized carapace, elongate subrectangular in lateral view, greatest height through the anterior cardinal angle, greatest length at mid-height. Anterior margin obliquely rounded, decorated with a double row of nodes, the inner one starting below the eye tubercle with small nodes which coincide in some specimens and form a thick anterior marginal rim which becomes thin along the ventral margin and terminates posteriorly with small node. The outer one forms the marginal flange, with fine marginal denticulations along the anterior margin of some specimens. In the male left valve posterior margin subtriangular, smooth, slightly curved in the upper part, with marked posterior cardinal angle, sloping down decorated with 4-5 small nodes in the lower part, pointed in the middle; in the male right valve the posterior end is slightly concave in the upper part, curving down in the lower part. In the female the posterior end is concave in the upper part sloping down in the lower part and

\section{Explanation of Plate 1}

All figures are stereoscopic paired photographs.

Figs. 1-6 Actinocythereis iraqe'nsis Khalal 1982

1. Paratype, 9 carapace from right, HU.275.T.7.1. X49

2. Paratype, + LV internal view, HU.275.T.8. X45

3. Paratype, 9 carapace from left, HU.275.T.7.2. X46

4. Holotype, $\sigma$ carapace from right, HU.275.T.6. X42

5. Paratype, o' RV internal view, HU.275.T.7.3. X46

6. Holotype, $\sigma$ carapace from left, HU.275.T.6. X42

Figs. 7-12. Actinocythereis costatu sp. nov.

7. Holotype, ơ carapace from left, HU.277.T.35. X51

8. Paratype, 9 RV internal view, HU.277.T.36.4. X58

9. Paratype, + carapace from left, HU.277.36.1. X48

10. Paratype, $\sigma^{\prime}$ carapace dorsal view, HU.277.T.36.2. X.55

11. Paratype, 9 carapace from right, HU.277.T.36.1. X48

12. Paratype, $q$ carapace dorsal view, HU.277.T.36.3. X56 


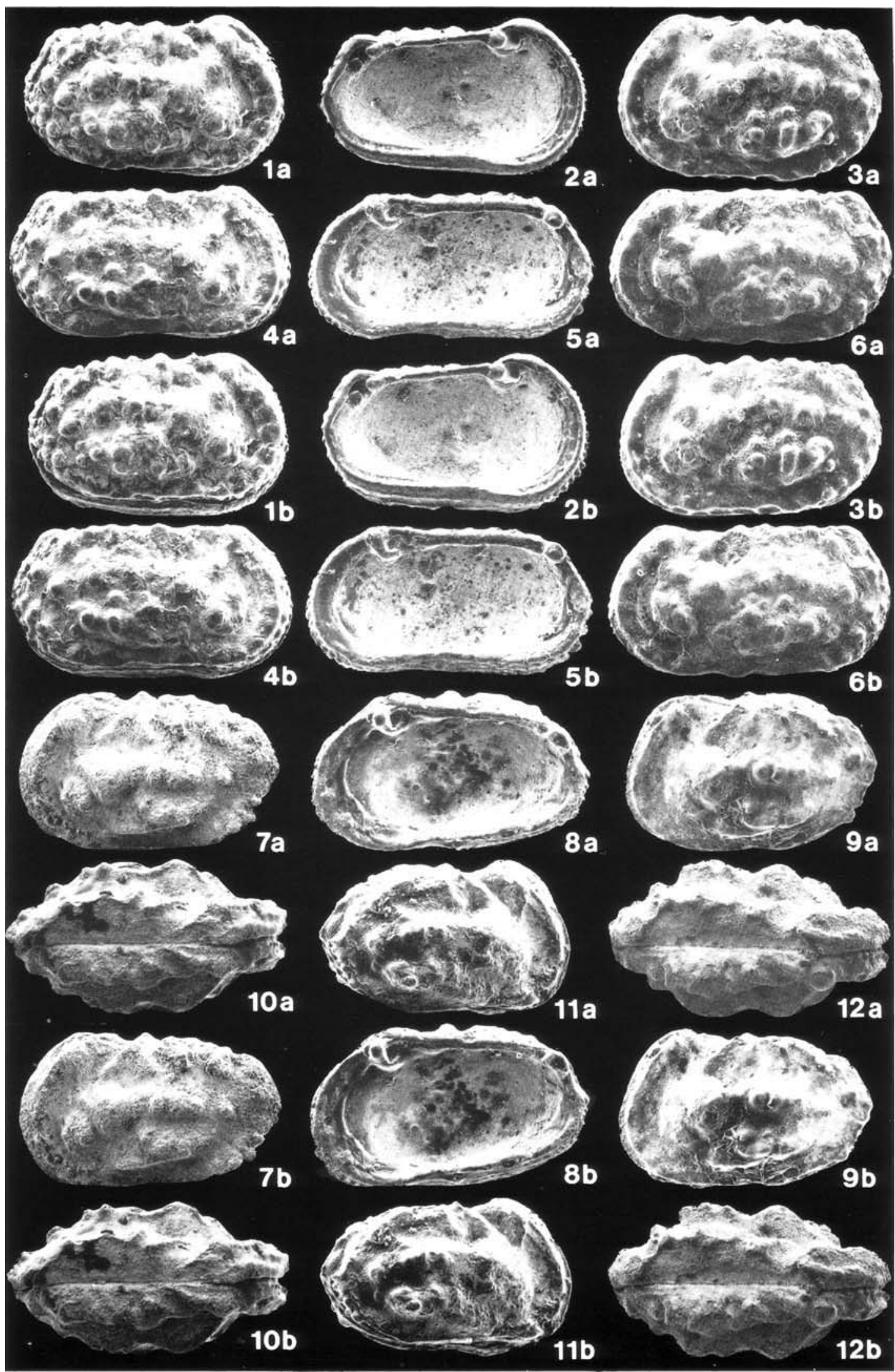


decorated with small nodes. Dorsal margin straight, jagged with small nodes and shallow furrows in between, the distinctive one behind the eye tubercle, running diagonally, bounded ventrally by a fine ridge which springs from the eye tubercle to join the subcentral tubercle. Anterior and posterior cardinal angles pronounced, ventral margin straight in male, concave anteriorly, curving upwards posteriorly in the female. Lateral surface decorated with tubercles or nodes which are variable in size. The median row starts anteroventrally, runs obliquely posteroventrally and consists of six nodes of which the anterior two are larger. The ventral row consists of four to five small nodes of which the first anterior two are double, these nodes are bounded ventrally by a short distinctive ridge.

The dorsal row consists of seven to eight small nodes with shallow furrows in between, which break up the dorsal margin outline. There is a rounded, prominent eye tubercle and prominent, ovate subcentral tubercle. Left valve Iarger than the right valve, overlapping it more distinctly along the posterior and ventral margins. Inner lamellar moderately wide with a distinct flange projecting anteriorly; line of concrescence and inner margin coincides and runs subperipherally to the outer margin. The selvage runs parallel to the anterior and posterior margin, not seen at midventral margin. Marginal pore canals are fairly numerous especially in the anterior portion. The muscle scars are typical of the genus, normal pore canals are fairly numerous, small and open. Hinge in the right valve consists of a strong outstanding anterior tooth, swinging ventrally with a short curved ridge to bound the deep, rounded postjacent socket, the posteromedian element is represented by a shallow, strongly crenulate, elongate groove, followed by a strongly outstanding subovate, posterior tooth with flattened surface. Eye sinus, deep very pronounced, below the anterior tooth. In dorsal view, the carapace outline is broken up by rows of lateral tubercles, anterior end broadly rounded, posterior end narrower and strongly pointed centrally, maximum width and thickness at the middle. The left valve strongly overreaches the right at the posterior cardinal angle. the sexes are easily distinguished, the males being more elongate, narrower and less high than the presumed females. This sexual dimorphism is well pronounced in dorsal view.

\section{Dimensions of figured specimens.}

Holotype $\sigma^{7}$ carapace HU.277 T.35 pl.1, fig.7.L=840 $\mu \mathrm{m}$, $\mathrm{H}=480 \mu \mathrm{m}$; Paratype + carapace HU.277 T.36.I pl. 1 , fig. 9,11 . $\mathrm{L}=815 \mu \mathrm{m}, \mathrm{H}=480 \mu \mathrm{m}$; Paratype 9 carapace HU.277 T.36.3 pl. 1, fig. 12. L $=820 \mu \mathrm{m}, \mathrm{H}=500 \mu \mathrm{m}, \mathrm{W}=490 \mu \mathrm{m}$; Paratype $\sigma^{7}$ carapace HU.277 T.36.2 pl. 1 , fig. $10 . \mathrm{L}=825 \mu \mathrm{m}, \mathrm{H}=460 \mu \mathrm{m}$, $\mathrm{W}=450 \mu \mathrm{m} ;$ Paratype RVI \& HU.277 T.36.4 pl. l, fig. 8 . $\mathrm{L}=790 \mu \mathrm{m}, \mathrm{H}=440 \mu \mathrm{m}$.

Remarks The Burmese subspecies Trachyleberis (Actinocythereis) birmanica kyankkokensis Gramann, 1975 has some similarities to the present species, but differs in being smaller and characterised by a single large node in the posterodorsal part of both valves, which is absent in the Iraqi species. Gramann's species has a very narrow rounded posterior end, which is substriangular in the present species.

In dorsal view, A. costata sp. nov. is thicker with a pointed posterior end. This species is easily distinguished from other Actinocythereis species by its distinctive posterior shape and the distribution of the lateral nodes.

Distribution. This species was found in the Sheikhan, Dohuk, Bai-Hassan, Sheikh Ibrahim and Kirkuk sections of the L. Fars Formation, Northern Iraq.

Actinocythereis cornuocula sp. nov.

Diagnosis. A species of Actinocythereis with prominent eye tubercle (horn-shaped) standing out strongly from the surface, a distinct posterior cardinal angle and a second dorsal spine sharply pointed backwards, the sexes are easily distinguished with the males more elongate and narrower than the females.

Explanation of Plate 2.

All figures are paired stereoscopic photographs.

Figs. 1-6 Actinocythereis cornuocula sp. nov.

1. Paratype, 9 carapace from right, HU.278.T.2.2. X57

2. Paratype, $q$ carapace dorsal view, HU.278.T.2.4. X64

3. Holotype, 9 carapace from left, HU.278.T.1. X60

4. Paratype, ơ carapace from right, HU.278.T.2.1. X59

5. Paratype, $\sigma^{\prime}$ carapace dorsal view, HU.278.T.2.1 X59

6. Paratype, $\sigma$ carapace from left, HU.278.T.2.3. X64

Figs. 7-10 Actinocythereis dextraspina sp. nov.

7. Holotype, 9 carapace from right, HU.278.T.3. X.59

8. Paratype, $\sigma^{7}$ carapace ventral view, HU.278.T.4.3. X59

9. Paratype, ơ carapace from right, HU.278.T.4.1. X57

10. Paratype, $\sigma^{7}$ RV internal view, HU.278.T.4.2. X58

Figs. 11, 12. Actinocythereis cornocula spinosa n.subsp.

11. Holotype, 9 carapace dorsal view, HU.278.T.5. X64

12. Holotype, 9 carapace from left. HU.278.T.5. X60 


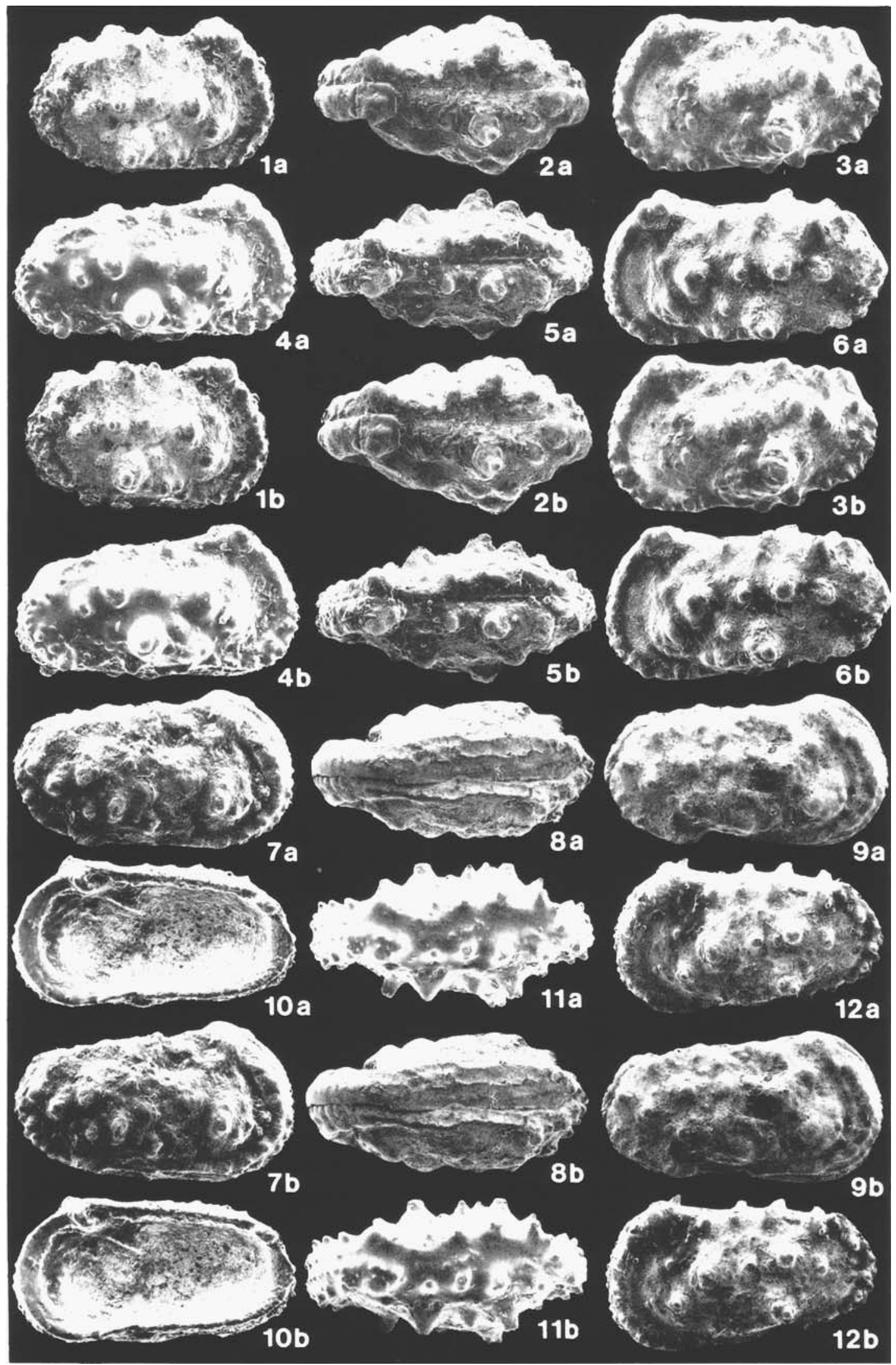


Actinocythereis cornuocula cornuocula subsp. nov. (Pl.2, figs. 1-6)

Derivation of name. oculus (Latin) $=$ eye, with reference to the horn-like nature of the eye tubercle-rocky.

Diagnosis. A subspecies of $A$. cormuocula with massive non-bifid median and ventral spines.

Holotype. A female carapace HU.278 T.I.

Paratypes. Four specimens HU.278. T.2, 1-4.

Type horizon. M. Miocene, L. Fars Formation, bed no.57, sample no. SHI.32.

Type locality. Sheikh Ibrahim anticline, S.limb, sheikh Ibrahim section (fig. 1). $45 \mathrm{~km} \mathrm{NW}$ of Mosul City.

Material. Forty specimens.

Description. Female carapace subquadrate in lateral view; male carapace elongate, subrectangular in side view; greatest height through the eye tubercle; greatest length below mid-height. Anterior margin obliquely rounded, with distinct marginal rim decorated with a double row of small nodes, of which the outer one consists of fine marginal denticulations; the inner one consists of small nodes in the upper part of the anterior margin and becoming sharp fringe along the lower part. Posterior margin truncated, sloping gently in the upper part, narrowly rounded in the lower. The upper part of the posterior margin is smooth, lower part decorated with a row of sharp spines; dorsal margin straight, sloping gently behind the eye tubercle, obscured in the posterior half by the dorsal spines. Anterior and posterior cardinal angles distinct, the anterior coinciding with the eye tubercle. Ventral margin straight to slightly convex, decorated with small fringes. Lateral surface strongly decorated with rows of prominent nodes and spines, the dorsal one consisting of three spines, sharply pointed upwards (particularly the middle one) and projecting over the dorsal margin; the median row runs obliquely from anteroventrally to posteroventrally and consists of five tubercles, the second of which is the largest and represents the subcentral tubercle; the ventral row consists of three nodes, the first two are small, the third one very large and prominent. Small nodes are scattered over the lateral surface. Hinge of the left valve consists of a deep ovate anterior socket, a rounded postjacent anteromedian tooth-followed by a longitudinal bar and quadriloculate posterior sockets; the terminal hinge elements are bounded dorsally by the projection of the anterior and posterior cardinal angles. Hinge of the right valve complementary. Eye sinus present below the anteroventral margin of the anterior socket. Line of concrescence and inner margin coincide and throughout run parallel to the outer margin, the selvage runs peripherally and a distinct marginal flange is present in each valve. Normal pore canals not numerous, open scattered over the valve surface. Other internal features are normal to the genus. Left valve slightly larger than the right, overlapping more conspicuously along the posterior margin. In dorsal view carapace biconvex, rounded anteriorly, narrow posteriorly, the ventrolateral spine or node forms a very distinctive lateral extension. Maximum thickness and width behind the middle.

Dimensions of figured specimens. Holotype $q$ carapace HU.278 T.I pl.2, fig.3, L=730 $\mathrm{m}, \mathrm{H}=415 \mu \mathrm{m}$; Paratype $q$ carapace HU.278 T.2.4 pl.2, fig.2, $\mathrm{L}=710 \mu \mathrm{m}, \mathrm{H}=410 \mu \mathrm{m}$; Paratype 9 carapace HU.278 T.2.2 pl.2, fig. $1, \mathrm{~L}=700 \mu \mathrm{m}$, $\mathrm{H}=410 \mu \mathrm{m}$; Paratype $\sigma^{\gamma}$ carapace HU.278 T.2.I pl.2, figs.4,5, $\mathrm{L}=790 \mu \mathrm{m}, \mathrm{H}=405 \mu \mathrm{m}$; Paratype $\sigma^{7}$ carapace HU. 278 T.2.3 pl.2, fig.6, $\mathrm{L}=740 \mu \mathrm{m}, \mathrm{H}=390 \mu \mathrm{m}$.

Remarks. The present species has some affinities with Trachyleberis (Actinocythereis, birmanica birmanica subsp. Gramann, 1975, but differs in being higher anteriorly, and wider posteriorly, in having a more distinct posterior cardinal angle and a well developed median row of five tubercles, and in the absence of a large posterodorsal node and in the truncated posterior margin.

A. cornuocula sp.nov. is closely related to Actinocythereis levinsoni Bhatia and Mandwal 1960, but the latter differs in being narrower, in the ventral margin fringed by eight flattened, coalescent spines, in the rounded anterior and posterior ends and the ventral row consisting of four individual tubercles. In addition, the present species differs in its horn-like eye tubercle and prominent, ventrolateral node.

Distribution. A. cornuocula was found at the Bashiqa, Dohuk, Sheikhan, Sheikh Ibrahim, and Hamrin localities of Northern Iraq.

\section{Actinocythereis cornuocula spinosa n.ssp.}

$$
\text { (Pl. 2, figs.11.12,) }
$$

Derivation of name: with reference to the well developed spines with bifid terminations.

Diagnosis. Lateral surface ornamented with three distinct rows of vertically tapering spines, of which the median and ventral spines are bifid.

Holotype. A female carapace HU.278 T.5.

Paratypes. Four specimens HU.278, T.6.4.

Type locality. Dohuk anticline, S.limb Dohuk section (fig. 1), $10 \mathrm{~km}$ NE of Dohuk City.

Type horizon. M.Miocene, L.Fars Formation, bed no. 12 , sample no. DO.II.

Material. Twenty specimens.

Description. Carapace elongate subrectangular in side view, greatest height at the anterior cardinal angle, greatest length passing through mid-height. Anterior margin obliquely rounded, decorated with a double row of spines and denticles, the first one consists of about thirty five marginal denticulations, the second one consists of seven small tubercles over the anterior marginal rim. Posterior margin, subtriangular slightly rounded at the middle, smooth in the upper part, decorated with a double row of fine pointed spines in the lower part. Dorsal margin straight, jagged with upward pointing tubercles; anterior and posterior cardinal angles prominent, the anterior one with a distinct eye tu- 
bercle; ventral margin straight at the middle, converging anteriorly and posterior. Lateral surface marked by three rows of tubercles and spines. The dorsal row consist of five backward-pointing spines which project above the dorsal margin; the median row consists of five, vertically pointing, spines running obliquely from anteroventrally to posteroventrally, of which the largest is the subcentral one; the ventral row consist of three spines, the first two are very small, the ventrolateral one is very prominent with a bifid head. Left valve larger than the right, overlapping conspicuously along the ventral and posterior margins. Inner lamella moderately wide with a distinct flange; selvage developed peripherally to the outer margin. Hinge in the right valve consists of a strong outstanding anterior tooth, forming a distinct arc ventrally, bounding a deep rounded socket, a flattened, outstanding posterior tooth, separated from the anteromedian element by a shall, longitudinal, crenulate groove. There is a marked eye sinus behind the anteroventral margin of the anterior tooth. Marginal pore canals numerous, some are thickened in the middle. Muscle scars indistinct.

Sexual dimorphism marked, the presumed males more elongate and narrower than the presumed females, and easily distinguished in dorsal view. In dorsal view both sides are jagged due to the upward-pointing tubercles and spines, anterior end rounded, posteriorly narrowly rounded with the maximum width and thickness behind the middle.

\section{Dimensions of figured specimens:}

Holotype $\$$ carapace HU.278 T.5.pl.2, fig. $11, \mathrm{~L}=730 \mu \mathrm{m}$. $\mathrm{H}=390 \mu \mathrm{m}$.

Remarks The present species resembles Actinocythereis khariensis Khosla and Pant, 1982, but differs in having a broad anterior margin, straight ventral margin, and in details of ornamentation of which the ventral row has two small nodes and a large ventrolateral one instead of the four small nodes of Actinocythereis khariensis. In addition, the posterior margin of the Indian species is narrower than that in the Iraqi species.

Actinocythereis kutchensis has some similarities to the present species, but differs in the shape of the tubercles, which are mostly rounded in shape, with a distinctive tubercle over the posteroventral corner which is not seen in the Iraqi species.

Distribution. This species was found in the Bashiqa, Sheikhan, Dohuk, Sheikh Ibrahim and Kirkuk sections of the L.Fars Formation of Northern Iraq.

Actinocythereis dextraspina sp.nov. (Pl.2.figs. 7-10)

Derivation of name. spina (Latin) $=$ spine, in reference to the posteroventral spine which is developed in the right valve.

Diagnosis. A distinctive spine developed posteroventrally in the right valve only, anteroventral tubercle flattened, decorated with small nodes.
Holotype. A female carapace HU.278, T,.3.

Paratypes. Three specimens HU.278 T.4, 1-3.

Type locality. Bashiqa anticline, S.limb, Bashiqa section (fig.1), $28 \mathrm{~km}$ NE of Mosul City.

Material. Twenty specimens.

Description. Carapace elongate, subrectangular in side view, greatest height through the anterior cardinal angle. Dorsal margin straight, broken by the row of small nodes, ventral margin slightly convex, merging evenly into the anterior margin; joining the posterior margin with a posteroventral spine. Anterior margin obliquely rounded, decorated with a double row of small nodes and denticles. Anterior marginal rim distinct, posterior margin subtriangular to slightly rounded at the middle, decorated with fine spines, more conspicuous ventrally. Lateral surface ornamented with spines and nodes which are not well developed, the biggest one being the anteroventral tubercle, the spines more distinct posteriorly. Eye tubercle small and rounded, subcentral tubercle marked. Marginal area moderately broad, line of concrescence and inner margin coincide, selvage well developed running peripherally to the outer margin. Marginal pore canals moderate in number and elongate; some of them are paired in the anterodorsal part. Posterior marginal area narrower with fewer marginal pore canals. Sexual dimorphism pronounced, the presumed males more elongate and narrower than the presumed females.

Dimensions of figured specimens Holotype $q$ carapace HU. 278 T.3 pl.2, fig.7, $\mathrm{L}=785 \mu \mathrm{m}, \mathrm{H}=460 \mu \mathrm{m}$; Paratype $\sigma^{7}$ carapace HU.278 T.4.1 pl.2, fig. $8, \mathrm{~L}=830 \mu \mathrm{m}, \mathrm{H}=430 \mu \mathrm{m}$, Paratype $o^{7}$ carapace HU.278 T.4.3 pl.2, fig.9, $\mathrm{L}=800 \mu \mathrm{m}$, $\mathrm{H}=440 \mu \mathrm{m}$; Paratype $\sigma^{7} \mathrm{RV}$ HU.278 T.4.2 pl.2, fig. 10, $\mathrm{L}=810 \mu \mathrm{m}, \mathrm{H}=460 \mu \mathrm{m}$.

Remarks The present species differs from A. cornuocula sp.nov. in having a distinctive posteroventral spine developed in the right valve only, and in the tubercles being comparatively weakly developed compared with other Actinocythereis species.

The present species shows some similarities to Actinocythereis spinellosa var. valdiyai Singh and Misra 1968, but the latter differs in being narrower, with well developed tubercles and spines coupled with the absence of a posteroventral spine, which is diagnostic in the present species.

Distribution. This species was found at the Bashiqa and Dohuk localities of Northern Iraq.

\section{ACKNOWLEDGEMENTS}

I would like to express my sincere gratitude to Professor J. W. Neale for critically reading this paper, and for the use of Department facilities at Hull University.

\section{Manuscript received August 1986 \\ Revised manuscript accepted May 1989}

\section{EDITORIAL NOTE}

Prof. J. W. Neale kindly rephotographed the specimens and made the two plates. 


\section{REFERENCES}

Bhatia, S.B., and Mandwal, M.K., 1960. Burdigalian Ostracoda from the surat Broach area, western India, Jour. Pal, 34(2), 280-284, pl.4l.

Gramann, F. 1975. Ostracoda from Tertiary Sediments of Burma with reference to living species. Geol.Jh.B.14.s, 1-46, 3 Abb. 5Taf. Hannover.

Guha, D.K. 1974. Marine Ostracoda from Tertiary of Kutch and Cambay. Panjab Univ. centre Advanced study Geol., Publ., 10., 156-176, pls, l-z.

Khalaf, S.K. 1982. On Actinocythereis iraquenis sp.nov. Stereo-Atlas of Ostracod shells, (9), 51-54.

Khalaf, S.K. 1984. Middle Miocene Ostracodafrom Northern Iraq, Unpublished Ph.D.Thesis, University of Hull, 364 pp. $41 \mathrm{pl}$.

Khosla, S.C. 1972. Ostracodes from the Eocene Beds of Rajasthan, India. Micropaleontology 18(4), 476-507, pls. $1-3$.

Khosla, S.C. 1978. Lower Miocene Ostracoda from Jamnagar and Porbandar Districts Gujarat, India. Micropal, 24, no. 3, 251-2 90,pls. 1-6.
Khosla, S.C. \& Pant, P.C. 1981. Ostracode genus Actinocythereis from the Eocene and Oligocene beds of Kutch. Proc. IX Indian coll. Micropal. strat. 167-180.

Lyubimova, P.S. Guha, D.K. and Mohan, M. 1960 . Ostracoda of Jurassic and Tertiary deposits from kutch and Rajasthan (Jaisalmer). India Geol. Min. Metall Soc. India, Bull. 22, 1-61, pls. 1-40.

Puri, H.S. 1953. Contribution to the study of the Miocene of the Florida panhandle. Bull.Fla. St.Geol. Surv', 215-309, pl.5, 1-17, figs. 1-13.

Singh, S.N., and Misra, P.C., 1968 New genus and species of Ostracodes from Fullere Earth, Kolayatji. Bikaner, Rajasthan India, Pal. Soc. India. Jour., 11, 26-37, pls. 711.

Tewart, B.S. and Tandon, K.K., 1960 kutch Microfauna Lower Tertiary Ostracoda. India, Nat. Inst. Sci.. proc.

ser. B.26 (4), 148-167. 